PAEDAGOGIA ChristianA

2/24 (2009) - ISSN 1505-6872

Piotr Chrzczonowicz ${ }^{*}$

Toruń

\title{
Sekty - wolność czy zniewolenie? Zagadnienia interdyscyplinarne, Toruń, 26 listopada 2009 r.
}

W dniu 26 listopada 2009 r., w gmachu Wydziału Teologicznego Uniwersytetu Mikołaja Kopernika w Toruniu, odbyła się konferencja naukowa „Sekty wolność czy zniewolenie? Zagadnienia interdyscyplinarne". Konferencja ta była wspólnym przedsięwzięciem organizacyjnym Katedry Prawa Karnego i Polityki Kryminalnej Wydziału Prawa i Administracji UMK, Katolickiego Stowarzyszenia "Civitas Christiana” Oddział Okręgowy w Toruniu, Toruńskiego Centrum Informacji o Sektach i Ruchach Religijnych, Wydziału Teologicznego UMK, Katedry Dydaktyki i Mediów w Edukacji Wydziału Nauk Pedagogicznych UMK, Europejskiego Stowarzyszenia Studentów Prawa ELSA Grupa Lokalna w Toruniu, Studenckiego Koła Naukowego UMK „Klub Debat Studenckich”, Towarzystwa Naukowego Organizacji i Kierownictwa „Dom Organizatora” w Toruniu, Samorządu Województwa Kujawsko-Pomorskiego, Wydziału Zdrowia i Polityki Społecznej Urzędu Miasta Torunia oraz Instytutu Wydawniczego PAX w Warszawie. Konferencja objęta została Patronatem Honorowym Marszałka Województwa Kujawsko-Pomorskiego Pana Piotra Całbeckiego, Jego Magnificencji Rektora UMK Pana prof. dr. hab. Andrzeja Radzimińskiego, Prezydenta Miasta Torunia Pana Michała Zaleskiego, Jego Ekscelencji Biskupa Ordynariusza Toruńskiego Ks. dr. Andrzeja Suskiego, Dziekana Wydziału Prawa i Administracji UMK Pana prof. dr. hab. Andrzeja Sokali oraz Dziekana Wydziału Teologicznego UMK Ks. prof. dr. hab. Jana Perszona. Patronat medialny nad konferencją sprawowały: Telewizja Polska S.A. Oddział w Bydgoszczy, Telewizja Internetowa Torun24.tv,

\footnotetext{
* Mgr Piotr Chrzczonowicz, asystent w Katedrze Prawa Karnego i Polityki Kryminalnej Wydziału Prawa i Administracji UMK w Toruniu.
} 
Radio Plus Toruń, „Gazeta Pomorska”, „Edukacja Prawnicza” oraz „Nasz Głos” - miesięcznik Katolickiego Stowarzyszenia „Civitas Christiana”.

Konferencja dotyczyła szerokiego spektrum zagadnień związanych z działalnością kontrowersyjnych grup i organizacji określanych potocznie mianem sekt. W prezentowanych referatach i wystapieniach podczas dyskusji uczestnicy konferencji koncentrowali się na wpisujących się w kontekst funkcjonowania sekt kwestiach prawnych (tu zwłaszcza akcentowano kwestie karnoprawne), socjologicznych, pedagogicznych, psychologicznych, filozoficznych, teologicznych i religioznawczych. Zagadnienia te prezentowali zarówno teoretycy, jak i praktycy - osoby związane z kilkoma ważnymi ośrodkami naukowymi w Polsce oraz instytucjami zajmującymi się upowszechnianiem informacji o zagrożeniach płynących z działalności sekt, jak również świadczącymi wielowymiarową pomoc osobom uwikłanym w sekty bądź je opuszczającym oraz rodzinom takich osób. Zasadniczym celem konferencji była wymiana poglądów i doświadczeń przedstawicieli środowisk eksperckich - naukowych i społecznych. Wydaje się, iż cel ten został osiagnięty w sposób wysoce satysfakcjonujący.

Podczas konferencji swoje referaty wygłosili uczeni i praktycy z Torunia, Krakowa, Warszawy, Gdańska, Olsztyna, Lublina, Katowic, Bielska-Białej, Wrocławia i Stalowej Woli. Obszerny i napięty, ale w pełni zrealizowany program konferencji obejmował trzy sesje oraz przewidywał czas na wspólną dyskusję.

W ramach pierwszej sesji (której przewodniczył ks. prof. dr hab. Jerzy Bagrowicz z Wydziału Nauk Pedagogicznych oraz Wydziału Teologicznego UMK) referaty wygłosili: ks. prof. dr hab. Andrzej Zwoliński z Katedry Katolickiej Nauki Społecznej Wydziału Nauk Społecznych Uniwersytetu Papieskiego Jana Pawła II w Krakowie (Bez doktryny. Sekty jako przejaw religii bez Boga), ks. mgr Grzegorz Daroszewski z Centrum Informacji o Sektach i Nowych Ruchach Religijnych przy Fundacji Przeciwdziałania Uzależnieniom U.N.A.S. w Gdańsku, pełniący także funkcję diecezjalnego duszpasterza osób i rodzin zagrożonych działalnością sekt (Zjawisko sekt w nauczaniu Kościoła Katolickiego za pontyfikatu Jana Pawła II), o. dr Mariusz Gajewski SJ z Wyższej Szkoły Filozoficzno-Pedagogicznej „Ignatianum” w Krakowie oraz Collegio Internazionale del Gesù w Rzymie (Samowykluczenie społeczne jako wynik przynależności do kontrowersyjnej grupy kultowej - geneza i uwarunkowania zjawiska), ks. dr Andrzej Wołpiuk reprezentujący Podbeskidzkie Centrum Informacji o Sektach i Grupach Psychomanipulacyjnych „VERITAS” w Bielsku-Białej (Czy naprawdę jesteśmy bezradni wobec działalności sekt? - główne punkty działań profilaktycznych wobec aktywności sekt i grup psychomanipulacyjnych), prof. dr hab. Robert T. Ptaszek z Katedry Teorii Religii i Alternatywnych Ruchów Religijnych Wydziału Filozofii Katolickiego Uniwersytetu Lubelskiego Jana Pawła II (Co działalność alternatywnych ruchów religijnych mówi o wspótczesnym człowieku i jego religijności?), mgr Dariusz Pietrek ze Ślaskiego Centrum Informacji o Sektach i Grupach Psychomanipulacyjnych KANA w Katowicach (Manipulacja pojęciami - psychoterapia, terapia $w$ tzw. sektach terapeutycznych $i$ ideolo- 
gii New Age) oraz dr Piotr Czarnecki z Instytutu Religioznawstwa Uniwersytetu Jagiellońskiego w Krakowie (Kosmiczna reinterpretacja Biblii - doktryna Ruchu Raeliańskiego).

W drugiej sesji (odbywającej się pod przewodnictwem prof. dr. hab. Roberta T. Ptaszka z KUL Jana Pawła II) swoje wystapienia przedstawili: prof. dr hab. Maciej Szostak z Katedry Kryminalistyki Wydziału Prawa, Administracji i Ekonomii Uniwersytetu Wrocławskiego (Metodologiczne problemy badawcze tzw. sekt destrukcyjnych), dr Marta Romańczuk-Grącka z Katedry Prawa Karnego Materialnego Wydziału Prawa i Administracji Uniwersytetu Warmińsko-Mazurskiego w Olsztynie (Przeszkody kryminalizacyjne dotyczqce zachowań zwiazanych ze zjawiskiem psychomanipulacji w sektach destrukcyjnych), Alicja Stańco, studentka Wydziału Politologii i Studiów Międzynarodowych UMK (Przemoc w sektach), mgr Anna Łobaczewska z Ruchu Obrony Rodziny i Jednostki w Lublinie (Subkultury młodzieżowe - czy już destrukcyjne uzależnienie mentalne?), dr Piotr T. Nowakowski z Katolickiego Uniwersytetu Lubelskiego Jana Pawła II - Wydziału Zamiejscowego Nauk o Społeczeństwie w Stalowej Woli (Problem egzagerowania $w$ debacie publicznej zagrożeń zwiazanych z działalnościq sekt) oraz red. mgr Andrzej Wronka ze Stowarzyszenia Ruch Effatha im św. Maksymiliana Marii Kolbego i św. Andrzeja Boboli (Ograniczanie norm poznawczych jako przyktad zniewalania w sektach $i$ ideologiach).

Podczas III sesji konferencyjnej (której przewodniczył prof. dr hab. Maciej Szostak z UWr.), z referatami wystapili: mgr Dariusz Hryciuk z Centrum Przeciwdziałania Psychomanipulacji w Lublinie (Sposoby prezentowania sekty w filmie), red. mgr Przemysław Semczuk reprezentujący tygodnik "Newsweek Polska” (PRL jako fundament Nowych Ruchów Religijnych. Sekty i Nowe Ruchy Religijne we wspótczesnych mediach), dr Hanna Karp z Wyższej Szkoły Kultury Społecznej i Medialnej w Toruniu (Maski sekt. Sekty w obliczu komercjalizacji rynku religijnego), mgr Joanna K. Frankowiak z Katedry Pedagogiki Ogólnej Wydziału Nauk Społecznych UWM w Olsztynie (,Zostań sobq”- program profilaktyczny zmniejszajacy podatność na działanie grup psychomanipulacyjnych), mgr Monika Mancewicz z Wydziału Nauk Społecznych UWM w Olsztynie (Współczesna szkoła w obliczu progresji zjawiska sekt), prof. dr hab. Viara Maldjieva z Instytutu Filologii Słowiańskiej UMK w Toruniu (Test „Credo”. Analityczna lektura współczesnych tekstów posługujacych się terminologia chrześcijańska), mgr Paweł Szuppe z Dominikańskiego Ośrodka Informacji o Nowych Ruchach Religijnych i Sektach w Warszawie (Ruch volkistowski jako forma nowej religijności $w$ Niemczech XIX $i$ XX w.), mgr Mirosław Salwowski z Torunia, publicysta katolicki (Czy pierwsi chrześcijanie byli sekciarzami? Drogi i bezdroża ruchu antysektowego) oraz Szymon Piotr Matusiak reprezentujący Chrześcijański Ośrodek Edukacyjny „Berea” (Jak rozmawiać ze Świadkami Jehowy?).

Cechą wspólną wszystkich prezentowanych referatów był ich znaczny walor poznawczy, a różnorodność zagadnień w nich poruszanych i interesujące ich omówienie (również przy wykorzystaniu aparatury do prezentacji multimedial- 
nych) nie tylko pozwoliły na utrzymanie wysokiej frekwencji wśród słuchaczy w trakcie całej konferencji, ale były też źródłem cennych bodźców dla odbywającej się następnie dyskusji.

W czasie dyskusji uczestnicy konferencji mogli zadawać pytania referentom oraz przedstawiać swoje refleksje odnośnie do wysłuchanych wystąpień. Poprowadzili ją: prof. dr hab. Maciej Szostak z Katedry Kryminalistyki WPAiE UWr., mgr Ireneusz Kamiński - dyrektor Toruńskiego Centrum Informacji o Sektach i Ruchach Religijnych oraz mgr Piotr Chrzczonowicz z Katedry Prawa Karnego i Polityki Kryminalnej Wydziału Prawa i Administracji UMK. Głos w dyskusji zabrali: dr Agata Skorek z Wydziału Administracji Szkoły Wyższej im. Pawła Włodkowica w Płocku, dr Hanna Karp, red. mgr Andrzej Wronka, mgr Anna Łobaczewska, ks. mgr Grzegorz Daroszewski, mgr Iryna Sheiko-Ivankiv z Ukrainy (uczestniczka Programu Stypendialnego Rządu RP dla Młodych Naukowców, przebywająca w UMK), Tomasz Lenz (poseł na Sejm RP VI kadencji), mgr Mirosław Salwowski, Krzysztof Paśniewski z Toruńskiego Centrum Informacji o Sektach i Ruchach Religijnych, prof. dr hab. Maciej Szostak, mgr Ireneusz Kamiński oraz mgr Piotr Chrzczonowicz.

Dyskusja miała żywy i intensywny przebieg, wskazując między innymi na problemy łączące się z używaniem $\mathrm{w}$ debacie publicznej i środkach masowego przekazu pojęcia „sekta” w odniesieniu do różnych wspólnot religijnych, w tym do uznanych w świetle obowiązującego w Polsce prawa i mających legalny status Kościołów czy związków wyznaniowych. Akcentowano w niej, że pojęcie „sekta”, odbierane w społeczeństwie z reguły negatywnie, może mieć charakter stygmatyzujący pewne mniejszości religijne (korzystające z gwarantowanych im w demokratycznym państwie praw i wolności oraz respektujące istniejący porządek prawny) i wyzwalać wobec nich postawy niechęci, nietolerancji, wrogości czy agresji. W dyskusji ponadto pojawił się wątek konieczności rozważenia skuteczniejszego zaangażowania autorytetu państwa i prawa do reagowania wobec różnych zjawisk patologicznych związanych z aktywnością w Polsce niektórych kontrowersyjnych grup o charakterze religijnym czy parareligijnym, w odniesieniu do których posłużono się określeniem „sekty destrukcyjne” (np. wobec tzw. psychomanipulacji).

Warto dodać, że materiały z konferencji - według zamysłu jej organizatorów - zostaną utrwalone w postaci publikacji książkowej. 